\title{
S63-04
}

\section{STRESS RESPONSIVITY IN CHILDHOOD AND ADULTHOOD: ROLE OF THE GLUCOCORTICOID RECEPTOR GENE}

S. Claes ${ }^{1}$, D. van West ${ }^{2}$, J. Del-Favero ${ }^{3}$, D. Deboutte ${ }^{2}$

${ }^{1}$ Department of Psychiatry, University Hospitals Leuven, Leuven, ${ }^{2}$ University Centre Child and Adolescent Psychiatry, ${ }^{3}$ VIB8, University of Antwerpen, Antwerpen, Belgium

Aims: Prenatal stress has been associated with lifelong disturbances in stress response systems and with an increased vulnerability for psychiatric disorders. However, the effect of prenatal stress is at least partially determined by individual genetic makeup. Recent data confim the potential role of the glucocorticoid receptor (GR) gene in modulating stress response and in the liability to develop mood disorders. In genetic association studies, single nucleotide polymorphisms (SNPs) in the GR gene were linked to variation in stress response systems (1). In a preliminary investigation, we studied 106 prepubertal children to estimate the impact of four GR gene polymorphisms on cortisol responses after a psychosocial stress test.

Results: Carriers of the ER22/23EK mutation displayed significant lower cortisol responses to psychosocial stress compared to noncarriers. This particular polymorphism has earlier been associated to the vulnerability to develop MDD by our own research group (2) and independently by another publication (3).

Conclusion: These findings support the relevance of GR gene polymorphisms in general and of the ER22/23EK polymorphism in particular in HPA axis regulation and in the vulnerability for psychiatric disorders.

1) Derijk RH \& de Kloet ER. Eur J Pharmacol. 583: 303-11, 2008.

2) van West $D$ et al. Neuropsychopharmacol 31: 620-7, 2006.

3) Van Rossum EFC et al., Biol Psychiatry 59: 681-688, 2006. 